\title{
A review of common diseases of pineapple: the causal pathogens, disease symptoms, and available control measures
}

\author{
1,2, ${ }^{*}$ Sapak, Z., ${ }^{3}$ Mohd Faisol Mahadeven, A.N., ${ }^{1}$ Nurul Farhana, M.H., ${ }^{1}$ Norsahira, S. and \\ ${ }^{1}$ Mohd Zafri, A.W. \\ ${ }^{I}$ Centre of Postgraduate Studies, Faculty of Plantation and Agrotechnology, Universiti Teknologi MARA \\ (UiTM), Jasin Campus, Merlimau, 77300 Melaka, Malaysia. \\ ${ }_{2}^{2}$ Sustainable Crop Protection Research Group, Universiti Teknologi MARA (UiTM), Shah Alam, 40450, \\ Selangor, Malaysia. \\ ${ }^{3}$ Agensi Nuklear Malaysia, Kompleks Jalan Dengkil, 43000 Bangi, Selangor, Malaysia.
}

\section{Article history:}

Received: 15 April 2021

Received in revised form: 2

June 2021

Accepted: 16 October 2021

Available Online: 26

November 2021

Keywords:

Pineapple,

Pathogens,

Disease symptoms,

Control measures

DOI:

https://doi.org/10.26656/fr.2017.5(S4).004

\begin{abstract}
Pineapple is a perennial fruit-bearing tropical plant that belongs to the Bromeliaceae family, which has more than 2500 species. Pineapple is known excellent source of minerals and vitamins. It produces substantial calcium, potassium, glucose, the proteindigesting enzyme bromelain, fibre, vitamin A, B and C. In Malaysia, twelve registered varieties of pineapple have been introduced and commercially planted such as Moris (AC1), Sarawak (AC2), Gandul (AC3), Maspine (AC4), Josapine (AC5) Yankee (AC6) Moris Gajah (AC7), N36 (AC8), MD2 (AC9), View of Sunset (AC10), Madu Kaca (AC11), and Keningau Diamond (AC12). The disease is one of the important factors that can contribute to the huge losses of pineapple yield worldwide. This review paper aimed to discuss the main diseases of pineapple and their control management, particularly in Malaysia. The common diseases of pineapple that cause significant yield losses in the farms such as mealybug wilt-associated virus, bacterial heart rot, fruit collapse, butt rot, fruitlet core rot, black rot, yeasty and fusariosis are highlighted and discussed in detail on the causal pathogens, disease symptoms and signs, disease infection and development. The available control measures for managing pineapple diseases were also included in this paper.
\end{abstract}

\section{Introduction}

Pineapple (Ananas comosus) is one of the edible Bromeliaceae fruits, which is commercially cultivated and produced in the tropic and subtropic regions. The fruit becomes the second major highest tropical crop after mango, where Asia, South Central America and Africa pose as the leading pineapple producers in the world (Altendorf, 2019). Pineapple production in Malaysia is considered a relatively small scale compared to other top producing countries such as Costa Rica, Brazil, Philippines, China, India, and Thailand. Despite that, the pineapple industry in Malaysia has a good potential to escalate. This aspiration has been carried out by the Malaysian Pineapple Industry Board (MPIB) with the aim to help the pineapple industry to achieve significant export targets yearly. The first effort can be seen in 2014, where the export value increased to $\$ 30$ million (USD) as compared to \$26 million in 2013. In 2015, Malaysia has been placed as the $18^{\text {th }}$ largest pineapple producer in the world (Geryl, 2015).
Currently, the pineapple plantation areas in the country are 16,000 ha with a total production of 412,720 metric tons per year (MPIB, 2015; Noor Baiti et al., 2017). According to the MPIB Director-General, the country's production of pineapple had increased between three to five percent annually. For instance, in 2019 the country's pineapple production increased to RM 530 million compared to RM 502 million in 2018 which was a jump of about five percent, with export contributing about RM342 million (Bernama, 2019). Therefore, MPIB needs more Malaysian especially young generations to be involved in pineapple cultivation to take advantage of its huge export potential, especially coming from China. To encourage more people to be involved with pineapple cultivation, the MPIB has introduced five initiatives which are premium entrepreneur development individual or groups, sustainable pineapple production cluster development, premium integrated development, seedling entrepreneur development and export promotions (MPIB, 2017). Currently, there are 12 major varieties of 
pineapple grown by growers either small scale or large scale, including Morris, Sarawak, Gandul, Maspine, Josapine, Yankee, Morris Gajah, N36, View of Sunset, Madu Kaca, MD2 and Keningau Diamond. In pineapple, many factors could hamper the quantity and quality of pineapple productions and one of them is the disease. Diseases of pineapple are always associated with fungi, bacteria, viruses, and nematodes. These disease pathogens could destroy either major parts of the pineapple plant or the whole plant. In this review, the common and disastrous diseases of pineapple found in pineapple farms in Malaysia and other countries of pineapple producers are highlighted and discussed.

\section{Pineapple mealybug wilt}

\subsection{Causal agents}

Pineapple mealybug wilt (PMW) disease is present in pineapple cultivations throughout the world (Hutahayan, 2017; Nyarko and Asare-Bediako, 2019; Massé et al., 2021). The disease has an intriguing etiology and involves a unique relationship between viruses, mealybugs, and ants (Jahn et al., 2003; Dey et $a l ., 2018)$. Mealybugs are vectors of the virus and ants play as agents to spread the vector in pineapple farms. Mealybugs provide a food source called honeydew to ants, and ants provide protection from natural enemies and transportation to this vector. Several distinct virus species have been identified that are associated with this wilt disease on pineapple. According to Dey et al. (2018), there are two species of viruses from the Ampelovirus genus, which have been classified as pineapple mealybug wilt-associated virus subgroup I (PMWaV-1), subgroup II (PMWaV-2), subgroup III (PMWaV-3) and two putative of PMWaV-4 and PMWaV-5. The PMWaV-2 has a more complex RNA genome compared to PMWaV-1 and both viruses are commonly reported as the main strains to cause the disease (Sether and $\mathrm{Hu}, 2001$; Alvarez et al., 2015). However, recently there are many reports on PMWaV-3 as the strain that has been confirmed to cause PMW in some pineapple cultivation areas (Hernández et al., 2010; Nyarko and Asare-Bediako, 2019; Massé et al., 2021). All virus strains can be transmitted to pineapple plants by insect pests Dysmioccus brevipes and Dysmioccus neobrevipes. Both insect species have a special association with ants from genera Pheidole and Solenopsis. Many studies reported that the big-headed ant, Pheidole magacephala, is the most dominant ant species associated with $D$. brevipes and $D$. neobrevipes (Beardsley et al., 1982; Jahn et al., 2003: Dey et al., 2018).

\subsection{Disease symptoms}

Generally, the pineapple mealybug wilt (PMW) disease symptoms can be classified into two types which are slow wilt and quick wilt (Carter, 1933; Dey et al., 2018). In 1967, Carter gave a better explanation of the differences between these two types. The author also defined the slow wilt as one whose symptoms appear after mealybugs have been feeding on the pineapple plants for many months (Carter, 1967). The wilt symptom is most likely the result of the destruction of leaf tissue resulting from the feeding of large numbers of mealybugs. Meanwhile, quick wilt is observed approximately two months after a sudden period of feeding by many mealybugs. The symptoms of quick wilt in plants up to six months old include the colour change in the inner leaves either too yellow or pink (varies by varieties), loss of turgidity, browning of the leaf tips (dieback), curling, and drying up (Dey et al. 2018). In both quick wilt and slow wilt, the plant may die, fail to produce fruits, or produce malformed shape or smaller fruits than normal fruits if the plant does not recover. In the case of the plant recovered from the diseases, the new leaves can grow out of the centre of the plant (Carter, 1967). In a severe infection, the disease gradually spreads from the leaves to the roots that lead to root collapse. Sether and $\mathrm{Hu}$ (2002a) reported a $35 \%$ reduction in the yield of plants with wilt disease and noted that the earlier the expression of symptoms the greater the impact on fruit yields.

\subsection{Disease management}

A direct relationship between high PMW incidences in pineapple farms and high populations of mealybugs capable of transmitting the viruses was first revealed by Sether and $\mathrm{Hu}$ (2002a, 2002b). Since then, control of mealybug colonies is the predominant method for preventing the wilt disease in pineapple plants (Dey et al., 2018). Furthermore, Rohrbach et al. (2003) found that natural enemies of mealybugs can keep the mealybug population under control, however, the population of ants needs to be effectively controlled. The use of baits such as Amdro ${ }^{\circledR}$ and other insect regulators is a popular method for eliminating ant populations (Hughes et al., 2002; Dey et al., 2018). Besides ants, growers also use some insecticides such as Malathion ${ }^{\circ}$, Diazinon ${ }^{\circledR}$ and Nemacur ${ }^{\circledR}$ to control the population of mealybugs by dipping the planting materials before planting and then spraying in the farms (Araya, 2017a; Dey et al., 2018). However, there is a possibility this spray application of insecticides cannot reach mealybugs since the insects could hide within crowns and blossom cups of plants (Dey et al., 2018). Various cultural practices, such as the removal of old pineapple stumps, destroying wilt-infected plants and pineapples after the 
first ratoon harvest, and initiating fallow periods, have all been found to be effective for the integrated management of MWP. The use of biological controls for mealybugs is also carried out by some pineapple growers in Hawaii by using several potential natural enemies such as Lobodiplosis pseudococci Felt (Diptera: Cecidomyiidae), Nephus bilucernarius Mulsant (Coleoptera: Coccinellidae), and Anagyrus ananatis Gahan (Hymenoptera: Encyridae), however, none have provided sufficient control of mealybugs when ants are present (Carter, 1967). Fungal and bacterial pathogens of ants are rare because of the antibiotic exocrine secretions that ants produce.

\section{Heart rot and fruit collapse}

\subsection{Causal pathogen}

Bacterial heart rot and fruit collapse are caused by the bacterium Dickeya zeae syn. Erwinia chrysanthemi. The bacterial pathogen could attack different plant parts at a different growth stage, and it is responsible for soft rot diseases across a wide range of plant species (Yogendra Singh and Purohit, 2017; Nor et al., 2019). Fruit collapse is also commonly known as "Ghost disease" and "Exploding pineapple disease" (Department of Agriculture and Fisheries Queensland, 2018). The first incidence of bacterial heart rot of pineapple was reported in Malaysia in 1957 by Johnston and has since been described in Costa Rica, Brazil, and the Philippines (Rohrbach and Johnson, 2003; Kaneshiro et al., 2008; Ramachandran et al., 2015; Nor et al., 2019). The pathogen E. chrysanthemi is a Gram-negative bacterium from the family Enterobacteriaceae which consists of 18 species. These 18 species are divided into two main groups based on their characteristics namely necrogenic group (Amylovora group) and soft rot group (Carotovora group). The pathogen E. chrysanthemi belongs to the latter group and is regarded as the most commercially important soft rotting pathogens (Sahilah et al., 2008). This bacterial pathogen has a broad range of host plants and is not limited to the tropics but also the subtropics.

In pineapple, this pathogen causes both bacterial heart rot and fruit collapse. Its ability to infect a broad range of plants may be attributed to its ability to grow at higher temperatures compared to the other soft-rot bacteria. Virulence of E. chrysanthemi is related to the ability of its strains to produce large quantities of endopolygalacturonic transeliminase (Rohrbach and Johnson, 2003). This E. chrysanthemi bacterium was originally classified as the pectolytic Erwinia spp. but was then moved to the genus Pectobacterium and classified as Pectobacterium chrysanthemi. In 2005, Samson et al. proposed a new genus named as Dickeya and separated it into seven species namely Dickeya dianthicola, Dickeya dadantii, Dickeya zeae, Dickeya chrysanthemi, Dickeya dieffenbachia, Dickeya. paradisiaca and Dickeya Solani. Dickeya dadantii and $D$. zeae, as well as nine biovars which are similar to $E$. chrysanthemi (Czajkowski et al., 2015). In their study, two strains of $E$. chrysanthemi from pineapple host plants were identified as D. zeae strains from biovar 8 and $D$. dadantii strains from biovar 3 (Kaneshiro et al., 2008; Ramachandran et al., 2015).

The main source of inoculum is thought to be infested juice from freshly collapsed fruits and heart rot tissues (Rohrbach and Johnson, 2003; Sahilah et al., 2008). Rohrbach and Johnson (2003) also stated that infested material is less likely a major source since bacteria do not survive long on leaf surfaces. Infection of pineapple plants takes place via stomata. Bacteria are then transmitted to the site of infection through vectors such as ants, souring beetle, pineapple tarsonemid mite and flies by transporting the bacteria from other collapsed fruits to the flowers or from plants with bacterial heart rot. Environmental factors such as wind as well as windblown rain also help in the transmission of the disease. It is also observed that mechanical wounding promotes disease apart from burns from urease which provides the entry points for the bacteria (Rohrbach and Johnson, 2003). Entry into fruits however was established to be via the open flowers (Rohrbach and Johnson, 2003; Sahilah et al., 2008). These insects are believed to be attracted to the nectar available in the fruit. Once the bacteria enter the ovary, it remains latent until 2-3 weeks before ripening. At this stage, sugar levels increase while polyphenol oxidase levels decline (Rohrbach and Johnson, 2003).

\subsection{Disease symptoms}

The initial symptom of bacteria heart rot is indicated by a water-soaked lesion on the white basal portion of the central whorl. Within $72 \mathrm{hrs}$ the light brown streaks start to form on the lamina and mesophyll often filled with gas-forming and blister-like lesions, characteristic of the disease. Infection may then spread to the entire basal portion of all leaves of the central whorl before spreading to the whole length of the leaves, displaying an olive-green leaf colour and a bloated appearance (Kaneshiro et al., 2008; Sidik and Sapak, 2021). However, if the spread of lesions is halted, a dark infection border forms. Distinct blisters are displayed on the leaves with fully developed symptoms. As the infection progresses, a light brown exudate comes out of the blister and leaves would turn light brown to dark brown as the leaves slowly begin to rot. Typically, the pineapple heart and stem can be easily detached from the lower portion of the plant around 1-2 weeks after initial 
symptoms (Rohrbach and Johnson, 2003; Kaneshiro et al., 2008). Around 21 days after the initial infection, the whole infected area on the leaf eventually rots. However, young pineapple fruit may be latently infected, showing a rapid soft rot and collapse at maturity, a disease called pineapple fruit collapse (Rohrbach and Johnson, 2003; Kaneshiro et al., 2008; Ramachandran et al., 2015).

Unlike bacterial heart rot, leaf infection in fungal heart rot does not extend beyond the white basal portion into the mature green areas distinguishing the two diseases (Rohrbach and Johnson, 2003). For bacterial fruit collapse, the symptoms usually become visible on mature fruits 2-3 weeks before ripening characterized by an exudation of juice and release of rotten-smelling gas bubbles produced by fermentation (Rohrbach and Johnson, 2003; Kaneshiro et al., 2008). As the disease progresses, the pineapple fruit shell changes colour from purple to olive green. Dissection of infected fruit shows rotten cavities within the skeletal fibres within the fruit (Rohrbach and Johnson; Department of Agriculture and Fisheries Queensland, 2018).

\subsection{Disease management}

Once a pineapple plant is infected, the disease could destroy the whole plant and spread to other healthy plants. Therefore, the need for effective controls to contain the disease spread is crucial. To date, conventional techniques are used in the control of bacteria heart rot disease. The key factor to prevent low bacterial heart rot incidences from becoming widespread is through sanitation. Since infested juice provides the main source of inoculum, all infected plants must be destroyed or removed from the field. As for seed material, crowns or slips from plants showing symptoms of fruit collapse or from areas with a high incidence of fruit collapse should not also be used. Other than that, mechanical damage also plays a role in disease spreading and therefore should be kept minimum especially during the critical period when plants are susceptible to infection and when low levels of disease are present. Usage of miticide and insecticides also showed partial control of bacterial heart rot in the Philippines (Rohrbach and Johnson, 2003). Ant control is also practised in Malaysia to minimize the spread of disease from infected to healthy plants since ants are the main vectors of the pathogen (Department of Agriculture, Water and the Environment, Australia, 2012). Another measure employed in subtropical climates to prevent bacterial heart rot is by using resistant cultivars instead of the relatively susceptible cultivars (Rohrbach and Johnson, 2003). However, none of those techniques is satisfactory due to the resistant strains and the effect of chemical treatments on the environment (Nor et al., 2019). Despite exercising these cultural practices and control measures, disease incidence in Malaysia is $0-40 \%$ for these two diseases which indicates these measures are not fully able to prevent disease occurrence in new locations (Fisheries and Forestry, 2012). Presently, most of pineapple growers still apply chemical pesticides such as benomyl for managing both diseases in their farms. In our recent study showed that benomyl is no longer effective to inhibit the growth of $D$. zeae, however, chemical pesticides such as difenoconazole and mancozeb were found effectively to suppress the pathogen and reduce the disease severity in pineapple plants (Sidek and Sapak, 2021). A recent exploration of biological control agents such as Trichoderma asperellum with a good formulation would be an alternative control method to reduce the application of chemical pesticides in managing the disease in pineapple farms in Malaysia (Ishak et al., 2021).

\section{Fruitlet core rot}

\subsection{Causal pathogen}

Fruitlet core rot (FCR) affects pineapple fruits and normally the infected fruits become unfit for consumption. Many researchers attributed the disease to Penicillium funiculosum (Barker, 1926; Thompson, 1937; Lim and Robarch, 1980; Barral et al., 2020). At the same time, other studies associated the disease with the Fusarium spp. (Larsen, 1910; Gu et al., 2015; Barral et al., 2020; Vignassa et al., 2021). In 2010, Jacobs et al. used molecular tools to identify the causal pathogen and revealed that Fusarium ananatum is a responsible pathogen for FCR and this species is different from Fusarium guttiforme, the causal pathogen of Fusariosis. Later, $F$. ananatum was also identified on commercial pineapples from Costa Rica, Ecuador, Hawaii, and Honduras (Stępień et al., 2013) and in China (Gu et al., 2015). In Malaysia, Lim (1985) reported that $P$. funiculosum is a main causal pathogen of FCR from the diseased samples collected from Peninsular Malaysia. This fungal pathogen, $P$. funiculosum was renamed Talaromyces funiculosus (Samson et al., 2011; Yilmaz et al., 2014; Barral et al., 2020). A recent study by Ibrahim et al. (2017) claimed that there is no evidence of $F$. ananatum as a causal pathogen of FCR in this country, however, the authors found several species of Fusarium that are associated with fruit rot of pineapple sampled from several pineapple farms in Peninsular Malaysia including Fusarium proliferatum, Fusarium sacchari, Fusarium verticillioides and Fusarium spp. where Fusarium proliferatum is the most common species found from the infected tissues of fruit rot.

\subsection{Disease symptoms}

Disease symptoms of FCR can be described as the 
browning of the flesh under the blossom cup of mature fruit. The black spot can spread to the core but remains confined to the fruitlet (Barral et al., 2020). Normally, the browning flesh remains quite firm, dry rot type, and limited to a single infected fruitlet (Gu et al., 2015). This browning is the result of the oxidation of phenolic compounds into quinones by the enzymes polyphenol oxidase and laccase (Avallone et al., 2003). Several studies revealed that soluble and cell wall-bound phenolic acids in the pineapple fruit parenchyma increase significantly after the onset of the first symptoms of FCR (Steingass et al., 2015; Barral et al., 2019; Barral et al., 2020). These compounds provide antifungal activity on several species of fungi including causal pathogens of FCR (Barral et al., 2020).

\subsection{Disease management}

A common method used for controlling FCR in pineapple farms is the application of fungicides. Petty et al. (2005) showed that the application of a combination of two fungicides at flower induction gave a significant reduction in the total number of black spots per fruit. Besides chemical fungicides, the use of essential oils such as eucalyptus oil, as well as extraction oils from Acalypha wilkensiana and Syzygium aromaticum have shown positive results in controlling the disease (Adewuyi-Samuel et al., 2019). This disease is also associated with physical injuries on fruit skin due to sunburn and insect pests; therefore, most growers in Malaysia particularly for pineapple variety MD2 use either fruit foam net or netting to protect their pineapple fruits from direct sunlight.

\section{Butt and black rot}

\subsection{Causal pathogen}

Butt rot and black rot of pineapple are caused by the same fungal pathogen, Thielaviopsis paradoxa (de Seynes) Hohn (anamorph). This pathogen is an Ascomycetes fungus (Sánchez et al., 2007; Hewajulige and Wijesundera, 2014) and possess both asexual and sexual reproductive stages that represent the formation of anamorph and teleomorph states of fungi, respectively. The teleomorph state for T. paradoxa is known as Ceratocystis paradoxa (Dade) C. Moreau (Hewajulige and Wijesundera, 2014). Anamorph of T. paradoxa normally produces infective spores and thick wall resting spores during the growing season. The infective spores known as conidia can be divided into two, namely macrospores and microspores. The macrospores are responsible for the blackening of the infected tissue during the final stage of disease development. Meanwhile, Swaroop Kumar (2007) reported that mycelium and chlamydospores also can turn the infected tissues into black rot. In $T$. paradoxa, the chlamydospores or aleurioconidia act as resting spores to survive in the soil during critical conditions (Abdullah et al., 2009). Most of the time, the teleomorph state of $C$. paradoxa is seldom found in a natural setting, especially in a growing season. Ascospores produced by $C$. paradoxa are considered less virulent and only attack the host plant under stress conditions such as overwintering (Álvarez et al., 2012). Besides that, T. paradoxa also has a special mode of life which is known as a facultative parasitic fungus (Larsen, 1910; Reyes, 1999). Reyes (1999) reported that $T$. paradoxa may become a saprophyte when it is found on dead tissues and become a parasite when it infects healthy tissues. However, $T$. paradoxa is mainly considered as a wound parasite that seizes opportunity through the wound into hosts. This pathogen can be disseminated through wind, water, soil, insects, or rodents to cause the diseases (Elliott, 2006).

\subsection{Disease symptoms}

Butt rot is different from black rot and can be differentiated by the disease symptoms. The symptoms of butt rot can be clearly seen on the rotten tissues at the base of suckers, crowns, and slips stem tissues before or promptly after planting (Joy and Sindhu, 2012). The rate of infection increases during warm and wet conditions as these conditions are very suitable for pathogenic fungi to grow (Nurnadirah et al., 2018). Normally, the pathogen invades into the host plant via wounds or any microscopic cracks, leaving the basal stem tissue soft and stringy. As the infection progresses, the infected tissue will turn to grey-black and eventually decay (Rohrbach and Johnson, 2003; Joy and Sindhu, 2012; Nurnadirah et al., 2018). Consequently, the planting materials fail to grow, become stunted, and limit the production of pineapples in the field. Sometimes, there is confusion between butt rot symptoms and bacterial heart rot disease. The only difference is that the young leaves remain attached during stem tissue loss. Black rot is a well-known postharvest disease. The infection starts mainly at the broken peduncles during or after harvesting (Swaroop Kumar, 2007; Joy and Sindhu, 2012) but infection may also start through wounds, insect punctures or natural opening on the flesh region (Snowdon, 2010). Pineapple fruits that suffer from translucency will be more susceptible to black rot disease infection (Reyes et al., 2004). Translucent pineapple is more prone to mechanical injury and the leaking juice from the broken peduncle or damaged area makes them remain wet after harvest which in turn triggers the growth of fungal disease (Paull and Reyes, 1996; Chen and Paull, 2000; Reyes et al., 2004). The symptom of infection on the broken peduncle can be observed through the existence of circular and water-soaked spots. 
Then, the spots enlarge extending over the flesh region and making fruit watery, soft, and disintegrated with black patches (Wijesinghe et al., 2010). The black rot infection may occur before harvesting but the symptoms are rarely to be seen by farmers in the fields as the symptoms develop during storage (Snowdon, 2010; Adikaram and Abayasekara, 2012). Normally, the disease takes 3-4 days to develop after harvest (Joy and Sindhu, 2012). In Malaysia, Morris, Sarawak and MD2 pineapples were reported prone to this black rot disease (Thalip et al., 2015; Singh et al., 2018).

\subsection{Disease management}

There are several control methods in managing butt and black rots such as cultural, chemical, physical, and biological methods. For controlling butt rot, planting materials need to be handled with care during separation from the fruit or plant to avoid a big wound. The planting tools and equipment need to be sanitised properly to avoid contaminants from soils or infected areas. The butt of planting materials also should be exposed to sunlight while storage. During wet weather, the butt of planting materials should be treated with recommended fungicides (Joy and Sindhu, 2012). In Australia, triadimenol and propiconazole are used to control the disease, and $1 \%$ Bordeaux mixture, and $0.25 \%$ Copper oxychloride are used In India prior to the planting by dipping, spraying, or drenching (Joy and Sindhu, 2012). Untreated planting material with a high inoculum of $T$. paradoxa would increase the disease incidence up to 100\% (Rohrbach and Johnson, 2003; Sipes and Wang, 2017). Besides that, soil drainage should be improved and planting in the rainy season is preferably avoided (Joy and Sindhu, 2012). In addition, Nurnadirah et al. (2018) found four bacteria isolated from infected soil in the pineapple field that have strong antagonistic activity against $T$. paradoxa. All four bacteria were then identified morphologically as Pseudomonas sp., Bacillus sp., Chromobacterium sp. and Serratia sp. These findings suggested that the ability of biological control agents to control butt rot disease should be further explored in the future. As for controlling black rot disease, farmers are advised to minimise mechanical damage or wound during harvesting. Damaged fruits and cracks due to sunburnt should be eliminated before being marketed (Joy and Sindhu, 2012). The harvesting tools should also be sanitised properly to avoid infection on the broken peduncles. Sun drying of the peduncles also help to reduce the black rot incidence. Rohrbach and Johnson (2003) suggested dipping the broken peduncles into approved fungicides before stored at $9^{\circ} \mathrm{C}$ to preserve the quality of pineapple fruit. In Malaysia, the broken peduncles are dipped into benzoic acid and benomyl to control the severe infection (Eng, 2009). Acetic acid dip treatment of $4-5 \%$ was reported to be capable of reducing black rot disease of pineapple during seven days storage at $28 \pm 2{ }^{\circ} \mathrm{C}$ (Wijeratnam et al., 2006). Furthermore, Wijeratnam et al. (2005) proved that dipping the cut end of the pineapple peduncles into $54^{\circ} \mathrm{C}$ of hot water within 3 minutes successfully controlled the black rot disease. Biological control agents such as yeast of Pichia guilliermondii and fungus of Trichoderma asperellum were reported to control the pathogen of black rot disease (Reyes et al., 2004; Wijesinghe et al., 2010; Wijesinghe et al., 2011).

\section{Leaf spot, stem end rot and fruitlet rot}

\subsection{Causal pathogen}

Leaf spot diseases of pineapple are always considered less important unless the diseases severely attack the whole plant. Many leaf spot diseases have been reported on pineapple plants such as leaf spot caused by Exserohilum rostratum (Luo et al., 2012) and leaf spot caused by Curvularia clavata (Zhong et al., 2016) found in China. Leaf spot disease can also be caused by Chalara parodoxa as reported by Joy and Sindhu, (2012) in India. In Malaysia, leaf spot disease found on pineapple leaves has been associated with several Fusarium species as reported by Ibrahim et al. (2017). These fungal pathogens are considered important as they do not only attack leaves but also other pineapple plant parts such as butt (C. paradoxa) and fruits (Fusarium spp.). Recently, Kuruppu et al. (2020) reported that the fungus Neoscytalidium dimidiatum can cause stem-end rot of pineapple particularly on pineapple MD2 variety in Malaysia. In our research (unpublished data), this fungal pathogen can also cause brown leaf spot disease on pineapple leaf and fruitlet rot on pineapple fruit (Figure 1). However, the fungus can only cause severe infection on the leaves with injuries caused by insect pests or mechanical injury. For fruitlet rot, there is a high possibility that the fungus enters the fruit at the early stage of fruit development, 60 days after flower induction with hormone.

\subsection{Disease symptoms}

Luo et al. (2012) described that leaf spot disease caused by E. rostratum as grayish white to yellowishwhite spots emerged on the leaf surfaces that ranged from 1.0 to $2.4 \times 0.3$ to $0.7 \mathrm{~cm}$ in the early stage of infection. The spots also displayed a distinctive light brown to reddish-brown banding pattern on the edges. Later, several spots would often merge to form large lesions, covering more than $67 \%$ of the leaf surface, which can lead to plant death. Meanwhile, leaf spot symptoms caused by $C$. clavata are water-soaked, yellow, chlorotic, or necrotic spots and greyish-brown 


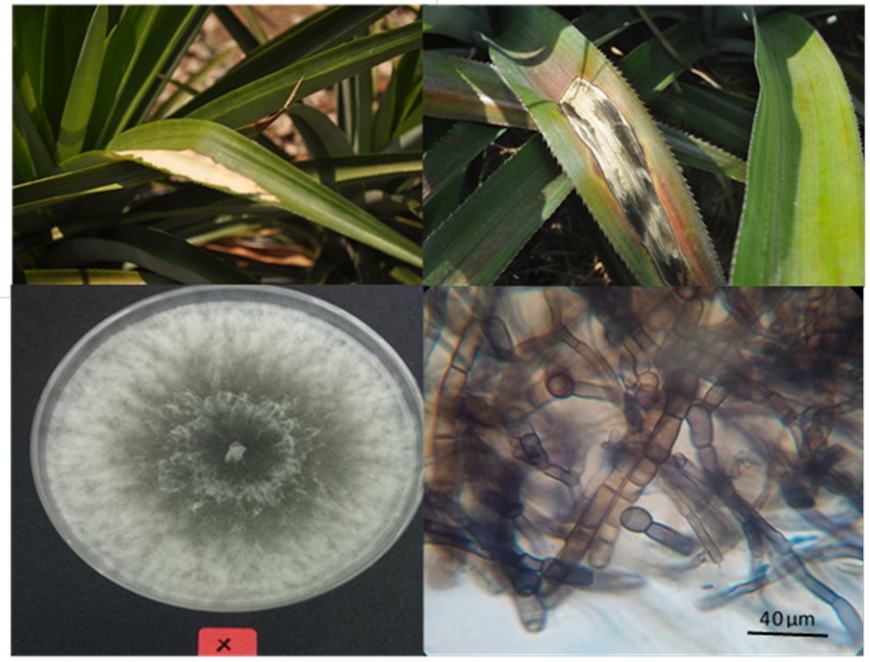

Figure 1. Leaf spot disease found on pineapple leaves in Perak in 2017. (a-b) The disease symptoms can be observed on the leaves when the infected area turns to cream then white in colour, but the margins of the spot often remain brown. (c-d) The fungal pathogen identified as Neoscytalidium dimidiatum grown on media and the microscopic structures under light microscope (40x magnification).

irregular lesions $(0.8$ to $4.2 \mathrm{~cm})$, predominantly on the leaf margin and main veins (Zhong et al., 2016). These two types of leaf spot diseases have not been recorded in Malaysia, however, Ibrahim et al., 2017 described the leaf spot disease caused by several species of Fusarium as small necrotic spots that changed to brown and darkbrown lesions as the disease developed. In our observation, leaf spot disease caused by $N$. dimidiatum started with small brown spots then eventually these spots lengthen rapidly to more than $20 \mathrm{~cm}$. Normally, the colour of the infected area turns cream or almost white, but the margins of the spot often remain brown (Figure 1). This fungal pathogen also causes stem-end rot disease and the disease symptoms have been explained by Kuruppu et al. (2020) as brown and rotten fruit skin near the stem end region or darker skin with black discolouration.

\subsection{Disease management}

Some of leaf spot diseases on pineapple are considered less importance, therefore, not many control methods have been proposed and discussed (Joy and Sidhu, 2012). In our observation in pineapple farms (unpublished data), this leaf spot disease occurred in relation to plant injuries due to sucking and chewing by insects. Controlling insect pests in the farms and maintaining a good sanitation could help to reduce these leaf spot diseases and other diseases.

\section{Fusariosis}

\subsection{Causal pathogen}

Fusariosis of pineapple is always associated with several species of Fusarium fungi. In Brazil, Fusarium guttiforme has been reported to cause the disease with an estimated loss of about 30-40\% (Carnielli-Queiroz et al., 2019). Meanwhile, Jacobs et al. (2010) demonstrated $F$. ananatum as the emerging species involved in pineapple fruit lesions in South Africa. Stępień et al. (2013) discovered that more species of Fusarium fungi could be associated with Fusariosis including Fusraium concentricum, Fusarium fujikuroi, Fusarium incarnatum, Fusraium oxysporum, Fusarium polyphialidicum, Fusarium proliferatum, Fusarium temperatum and Fusarium verticillioides based on diseased fruits collected from Costa Rica, Ecuador, Honduras, Hawaii, Indonesia, and Vietnam. In Peninsular Malaysia, Ibrahim et al. (2016) found that Fusarium fujikuroi is the causal pathogen of Fusariosis disease. In their phylogenetic analysis, the isolate of $F$. fujikuroi is grouped into different clades from $F$. proliferatum although morphologically, $F$. fujikuroi is similar to $F$. proliferatum. Besides $F$. fujikuroi, they also discovered other Fusarium species from infected fruits with fusariosis symptoms from varieties of Gandul, Josapine and Moris namely $F$. semitectum and $F$. chlamydosporum. Emerging new Fusarium species as causal pathogens of Fusariosis in Malaysia can be related to trading and exchange of planting materials between plantations (Ibrahim et al., 2016) .

\subsection{Disease symptoms}

Common symptoms of the disease are lesion and brown discolouration of the fruitlet, rotten or sunken fruit skin and stem, gum exudation on some fruits, dry rot on the leaf, stem bending, chlorosis, increasing number of leaves per spiral and natural cracks on the fruits (Korres et al., 2011; Ibrahim et al., 2016).

\subsection{Disease management}

A good culture practice by destroying crop residues in pineapple farms to avoid the emergence of resistant structures of fungal pathogens such as chlamydospores that could remain a long time in the soil is highly recommended, as discussed by Ventura et al. (1993). Sanitation and treatment of planting materials with fungicides such as benomyl or captafol have been conducted by most pineapple growers to reduce the disease incidence in the farms. Hot water treatment at the temperature of $54^{\circ} \mathrm{C}$ for $90 \mathrm{~min}$ is also suggested to reduce the disease infection on planting materials (Ventura et al., 1993). There were also many studies on producing new pineapple varieties which are resistant to the disease (Cabral and De Mantos, 2007; Ventura et al., 2009; Viana et al., 2020). The uses of biological control agents for controlling the disease have also been reported. Korres et al. (2011) studied the potential of 
yeasts, while De Souza et al. (2016) and Trocoli et al. (2017) studied the usage of Trichoderma spp. Besides microbes, an essential oil such as thyme oil is also used for controlling the pathogen (Vilaplana et al., 2018). However, the use of chemical fungicides remains the main method for controlling the disease in many pineapple farms. For instance, combinations of several fungicides such as azoxystrobin, cyproconazole, carboxin, thiram, tebuconazole and methyl thiophanate in different concentrations have been tested for Fusariosis control in the pineapple field in Brazil (Nogueira et al., 2014).

\section{Yeasty}

\subsection{Causal pathogen}

The yeasty disease of pineapple is caused by several species of yeast such as Hanseniaspora valbyensis, Saccharomyces spp. and Candida spp. (Rohrbach and Johnson, 2003). There are not many reports on the yeasty disease of pineapple in Malaysia. In our diseased fruit samples collected in Klang, Selangor in 2017 MD2 pineapple fruits have been attacked by yeast of Candida sp. (Unpublished data) and this species of yeast has also been reported in Brazil (Korres et al.,2010) and India (Joy and Sidhu, 2012).

\subsection{Disease symptoms}

Disease symptoms of yeasty can be described as bubbling exudation of gas and juice through the crack or injury on the infected area. The skin then turns olive green and the pulp becomes spongy. Finally, all that remains of the fruit is the shell and spongy tissue (Joy and Sindhu, 2012).

\subsection{Disease management}

The yeasty disease of pineapple is commonly found in mature fruit and the pathogen is easily widespread in overripe or damaged fruits. Preventing damage or injury on fruit skin from insect pests can reduce the disease incidence in the farms. Joy and Sidhu (2012) suggested removing any fruit showing fractures between fruitlets at the earliest stages of fruit maturity to minimise losses.

\section{Diseases caused by nematodes}

\subsection{Causal parasite}

Several species of parasitic nematodes have been reported on pineapple such as root-knot (Meloidogyne javanica and Meloidogyne incognita), lesion (Pratylenchus brachyurus) and reniform (Rotylenchulus reniformis) (Guerout, 1975; Rabie, 2017). The importance of nematodes that are responsible for the losses in pineapple farms have been recorded in Costa
Rica (Araya, 2017b), Peru (Vera Obando et al., 2017), France (Soler et al., 2021), Africa (Coyne et al., 2018) and Nigeria (Daramola et al., 2013). In Malaysia, Masdek et al. (2007) reported a high occurrence of Paratylenchus sp. and a low population of Aphelenchoides sp. and Pratylenchus sp. in commercial pineapple farms. The authors concluded that pineapple yield decline on peat soil was most likely due to the nematode Paratylenchus sp. This nematode was found throughout the growth stages of the crop and the highest population was observed on the oldest plants, especially in highly acidic peat soil (Masdek et al., 2007).

\subsection{Disease symptoms}

Pineapple plants infected by root-knot nematodes can be noted by the symptoms of galls that develop on the roots because of feeding by active second-stage juveniles (Rabie, 2017). A high number of galls and branching are an indication of severe root-knot nematode infection. This results in a stunted root system which makes the plants more susceptible to nutrient and moisture stress. Furthermore, root-knot nematode galls on pineapple roots may often be invaded by various fungi that cause the galls to turn black and rot internally (Back et al., 2002). Meanwhile, symptoms of root damage caused by lesion nematodes are hard to detect. Black, necrotic lesions may be visible where the nematodes penetrate but the lesion can extend across the entire root surface (Rabie, 2017). Although root growth continues after lesion nematode infection, it stops after penetration of the secondary roots by these pests. Root systems of pineapple plants infected with numerous lesion nematodes can be devoid of secondary roots and consist only of poorly developed primary roots (Sipes et al., 2005, Masdek et al., 2007). Infection by lesion nematodes ultimately destroys the parenchyma tissues of roots, while the cortex separates from the central cylinder (Guerout, 1975). Above-ground symptoms of nematode infected pineapple plants resemble the symptoms of nutrient deficiency. Severe root injury would disturb the nutrient uptake by the plant, especially potassium uptake, which would subsequently affect crop growth and would finally result in low productivity and low fruit quality (Masdek et al., 2007).

\subsection{Disease management}

Several control methods used by pineapple growers to manage nematode attacks include cultural practices, nematicides, biological control and integration of these available methods to achieve the best control management. Removal of infected plants from the fields is the most suggested method to reduce the incidence for the next planting. Application of nematicides has remained the most common short-term management 
strategy against nematodes (Hajihassani et al., 2019; Medina-Canales et al., 2019). Recently, several chemicals such as methyl bromide and aldicarb have been withdrawn from the market due to environmental and human health concerns and toxicity to non-target organisms (Kim et al., 2018; Xiang et al., 2018). Nevertheless, new products continue to become commercially available and are evaluated for nematode management. Currently, the uses of biological control agents such as Trichoderma spp. and Purpureocillium Lilacinum and essential oils, plant extracts, acids such as organic and amino acids, natural bioactive substances, green manure, and industrial wastes have been explored by many studies for managing nematode attacks on pineapple plants (Kiriga et al., 2018; Forghani and Hajihassani, 2020; Soler et al., 2021). Other strategies such as ozonated water (Veronico et al., 2017), silicon (Roldi et al., 2017) and steaming and solarization (Kokalis-Burelle et al., 2016) could be also as new strategies to control nematodes in pineapple farms.

\section{Conflict of interest}

The authors declare no conflict of interest.

\section{Acknowledgements}

The authors would like to acknowledge all contributors to this review paper either direct or indirect contributions. We also would like to thank the technical staff from the Faculty of Plantation and Agrotechnology, Universiti Teknologi MARA (UiTM) and Malaysian Pineapple Industry Board (MPIB) for their help. Some of our research findings that have been reported in this review were funded by the Malaysia Ministry of Higher Education under the Fundamental Research Grant Scheme (FRGS 600-IRMI /FRGS 5/3 (0124/2016).

\section{References}

Abdullah, S.K., Asensio, L., Monfort, E., Gomez-Vidal, S., Salinas, J., Lorca, L.V.L. and Jansson, H.B. (2009). Incidence of the two date palm pathogens, Thielaviopsis Paradoxa and T. Punctulata in soil from date palm plantations in Elx, South-East Spain. Journal of Plant Protection Research, 49(3), 276279. https://doi.org/10.2478/v10045-009-0043-z

Adewuyi-Samuel, O.B., Etaware, P.M., Shennaike, O.A. and Odebode, A.C. (2019). Bio-treatment of fruitlet core rot associated with fungi-induced postharvest deterioration in Ananas comosus Linn. (Pineapple). International Journal of Innovative Research and Advanced Studies, 6(8), 96-93.

Adikaram, N. and Abayasekara, C. (2012). Pineapple. In Rees, D., Farrel, G. and Orchard, J. (Eds.). Crop Post
-Harvest: Science and Technology Volume 3 Perishables, p. 143- 158. West Sussex, UK: Blackwell publishing Ltd. https:// doi.org/10.1002/9781444354652.ch7

Altendorf, S. (2019). Major tropical fruits market review 2018. Food and Agriculture Organization of the United Nations (FAO). Retrieved from FAO website: http://www.fao.org/3/ca5692en/ ca5692en.pdf.

Álvarez, E., Llano, G.A., Loke, J.B. and Chacon, M.I. (2012). Characterization of Thielaviopsis paradoxa isolates from oil palms in Colombia, Ecuador, and Brazil. Journal of Phytopathology, 160(11-12), 690700. https://doi.org/10.1111/jph.12012

Alvarez, R.A., Martin, R.R. and Quito-Avila, D.F. (2015). First report of pineapple mealybug wilt associated virus-1 in Ecuador. New Disease Reports, 31(1), $\quad 15 . \quad \mathrm{https} / / /$ doi.org/10.5197/j.20440588.2015.031.015

Araya, M, (2017b). Frequencies and population densities of parasitic nematodes in Costa Rican pineapple plantations. ISHS Acta Horticulturae, 1239, 153-166. https://doi.org/10.17660/ActaHortic.2019.1239.19

Araya, M. (2017a). Chemical control of mealybugs on pineapples. ISHS Acta Horticulturae, 1239, 147-152. https://doi.org/10.17660/ActaHortic.2019.1239.18

Avallone, S., Guiraud, J.P., Brillouet, J.M. and Teisson, C. (2003) Enzymatic browning and biochemical alterations in black spots of pineapple (Ananas comosus (L.) Merr.) Current Microbiology, 47, 113118. https://doi.org/10.1007/s00284-002-3958-4

Back, M.A., Haydock, P.P.J. and Jenkinson, P. (2002). Disease complexes involving plant parasitic nematodes and soil borne pathogens. Plant Pathology, 51(6), 683-697. https://doi.org/10.1046/ j.1365-3059.2002.00785.x

Barker, H.D. (1926). Fruitlet black rot disease of pineapple. Phytopathology, 16(5), 359-363.

Barral, B., Chillet, M., Doizy, A., Grassi, M., Ragot, L., Léchaudel, M., Durand, N., Rose, L.J., Viljoen, A. and Schorr-Galindo, S. (2020). Diversity and toxigenicity of fungi that cause pineapple fruitlet core rot. Toxins, 12(5), 339. https://doi.org/10.3390/ toxins 12050339

Barral, B., Chillet, M., Léchaudel, M., Lugan, R., and Schorr-Galindo, S. (2019). Coumaroyl-isocitric and caffeoyl-isocitric acids as markers of pineapple fruitlet core rot disease. Fruits, 74(1), 11-17. https:// doi.org/10.17660/th2019/74.1.2

Beardsley, J.W., Su, T.H., McEwen, F.L. and Gerling, D. (1982). Field investigations on the interrelationships of the big-headed ant, the gray pineapple mealybug, 
and pineapple mealybug wilt disease in Hawaii. Proceedings, Hawaiian Entomological Society, 24 (1), 51-67.

Bernama. (2019). MPIB wants to boost Malaysia's pineapple export. Retrieved from website: https:// www.malaymail.com/news/money/2019/10/22/mpib -wants-to-boost-malaysias-pineappleexport/1802654.

Cabral, J.R.S. and De Matos, A.P. (2007). Imperial, a new pineapple cultivar resistant to Fusariosis. Acta Horticulturae, 822, 47-51. https://doi.org/10.17660/ ActaHortic.2009.822.3

Carnielli-Queiroz, L., Fernandes, P.M.B., Fernandes, A.A.R. and Ventura, J.A. (2019). A rapid and reliable method for molecular detection of Fusarium guttiforme, the etiological agent of pineapple Fusariosis. Brazilian Archives of Biology and Technology, 62, e19180591. https:// doi.org/10.1590/1678-4324-2019180591

Carter, W. (1933). The spotting of pineapple leaves caused by Pseudococcus brevipes, the pineapple mealybug. Phytopathology, 23, 243-259.

Carter, W. (1967). Insects and related pests of pineapple in Hawaii: A manual for fieldman, p. 36-53. Honolulu, Hawaii, USA: Pineapple Research Institute of Hawaii.

Chen, C.C. and Paull, R.E. (2000). Sugar metabolism and pineapple flesh translucency. Journal of the American Society for Horticultural Science, 125(5), 558-562. https://doi.org/10.21273/JASHS.125.5.558

Coyne, D.L., Cortada, L., Dalzell, J.J., Claudius-Cole, A.O., Haukeland, S., Luambano, N. and Talwana, H. (2018). Plant-parasitic nematodes and food security in Sub-Saharan Africa. Annual Review of Phytopathology, 56, 381-403. https:// doi.org/10.1146/annurev-phyto-080417-045833

Czajkowski, R., Pérombelon, M.C.M., Jafra, S., Lojkowska, E., Potrykus, M., Van Der Wolf, J.M. and Sledz, W. (2015). Detection, identification, and differentiation of Pectobacterium and Dickeya species causing potato blackleg and tuber soft rot: A review. Annals of Applied Biology, 166(1), 18-38. https://doi.org/10.1111/aab.12166

Daramola, F., Afolami, S.O., Idowu, A.A. and Nwanguma, E.I. (2013). Studies on the occurrence and distribution of plant-parasitic nematodes in some pineapple-producing states in Nigeria. Asian Journal of Crop Science, 5, 190-199. https://doi.org/10.3923/ ajcs.2013.190.199

De Souza, J.T., Trocoli, R.O. and Monteiro, F.P. (2016). Plants from the Caatinga biome harbor endophytic Trichoderma species active in the biocontrol of pineapple Fusariosis. Biological Control, 94, 25-32. https://doi.org/10.1016/j.biocontrol.2015.12.005

Department of Agriculture and Fisheries Queensland (2018). Bacterial heart rot and fruit collapse of pineapple. Department of Agriculture and Fisheries Queensland, 1(1), 23-26. Retrieved from website: https://www.business.qld.gov.au/industries/farmsfishing-forestry/agriculture/crop-growing/prioritypest-disease/bacterial-heart-rot.

Department of Agriculture, Water and the Environment, Australia. (2012). Final import risk analysis report for the importation of fresh decrowned pineapple (Ananas comosus (L.) Merr.) fruit from Malaysia. Retrieved from website: https:// www.agriculture.gov.au/biosecurity/risk-analysis/ memos/2012/ba2012-27-final-malaysian-pineapples.

Dey, K.K., Green, J.C., Melzer, M., Borth, W. and Hu, J.S. (2018). Mealybug wilt of pineapple and associated viruses. Horticulturae, 4(4), 52. https:// doi.org/10.3390/horticulturae 4040052

Elliott, M.L. (2006). Thielaviopsis trunk rot of palm. Fact Sheet PP-219/PP143, 1/2006. Retrieved from https://edis.ifas.ufl.edu/. https://doi.org/10.32473/ edis-pp143-2006

Eng, L. (2009). Diseases of pineapple in Sarawak, p. 1 6. Kuala Lumpur: Jabatan Pertanian Sarawak.

Forghani, F. and Hajihassani, A. (2020). Recent advances in the development of environmentally benign treatments to control root-knot nematodes. Frontiers in Plant Science, 11, 00125. https:// doi.org/10.3389/fpls.2020.01125

Geryl, O.R. (2015). Malaysia Pineapple Industry Board looks to control five per cent of the global market. The Borneo Post Online. Retrieved from https:// www.theborneopost.com/2015/11/30/malaysiapineapple-industry-board-looks-to-control-five-percent-of-the-global-market/.

Gu, H., Zhan, R.L., Zhang, L.B., Gong, D.Q. and Jia, Z.W. (2015). First report of Fusarium ananatum causing pineapple fruitlet core rot in China. Plant Disease, 99(11), 1653. https://doi.org/10.1094/PDIS03-15-0279-PDN

Guerout, R. (1975). Nematodes of pineapple: a review. PANS Pest Articles and News Summaries, 21(2), 123 -140. https://doi.org/10.1080/09670877509411384

Hajihassani A., Davis, R.F. and Timper, P. (2019). Evaluation of selected nonfumigant nematicides on increasing inoculation densities of Meloidogyne incognita on cucumber. Plant Disease, 103, 31613165. https://doi.org/10.1094/PDIS-04-19-0836-RE

Hernández, L., Ramos, P.L., Rodríguez, M., Peña, I. and Pérez, J.M. (2010). First report of pineapple 
mealybug wilt associated virus-3 infecting pineapple in Cuba. New Disease Reports, 22(1), 18. https:// doi.org/10.5197/j.2044-0588.2010.022.018

Hewajulige, I.G.N. and Wijesundera, R.L.C. (2014). Thielaviopsis paradoxa, Thielaviopsis basicola (Black Rot, Black Root Rot). In Bautista-Baños, S. (Ed.), Postharvest Decay Control Strategies, p. 287304. London, UK: Academic Press, Elsevier. https:// doi.org/10.1016/B978-0-12-411552-1.00009-0

Hughes, W., Howse, P., Vilela, E., Knapp, J. and Goulson, D. (2002). Field evaluation of potential of alarm pheromone compounds to enhance baits for control of grass-cutting ants (Hymenoptera: Formicidae). Journal of Economic Entomology, 95 (3), 537-543. https://doi.org/10.1603/0022-049395.3.537

Hutahayan, A.J. (2017). Identification of distribution the pineapple mealybug wilt disease in the pineapple plant in North Tapanuli. International Journal of Environment, Agriculture and Biotechnology, 2(5), 238928. https://doi.org/10.22161/ijeab/2.5.26

Ibrahim, N.F., Mohd, M.H., Mohamed Nor, N.M.I. and Zakaria, L. (2017). Characterization of Fusarium spp. associated with pineapple fruit rot and leaf spot in Peninsular Malaysia. Journal of Phytopathology, 165(11-12), 718-726. https://doi.org/10.1111/ jph.12611

Ibrahim, N.F., Mohd, M.H., Nor, N.M.I.M. and Zakaria, L. (2016). Fusarium fujikuroi causing Fusariosis of pineapple in Peninsular Malaysia. Australasian Plant Disease Notes, 11(1), 1-6. https://doi.org/10.1007/ s13314-016-0206-5

Ishak, A.A., Zulkepli, F.R.A., Hayin, N.F.M., Zain, N.M. and Sapak, Z. (2021). Effect of high inlet temperature of spray dryer on viability of microencapsulated Trichoderma asperellum conidia. In IOP Conference Series: Earth and Environmental Science, 757(1), $012023 . \quad \mathrm{https}: / /$ doi.org/10.1088/1755-1315/757/1/012023

Jacobs, A., Van Wyk, P.S., Marasas, W.F., Wingfield, B.D., Wingfield, M.J. and Coutinho, T. (2010). Fusarium ananatum sp. nov. in the Gibberella fujikuroi species complex from pineapples with fruit rot in South Africa. Fungal Biology, 114, 515-527. https://doi.org/10.1016/j.funbio.2010.03.013

Jahn, G.C., Beardsley, J.W. and González-Hernández, H. (2003). A review of the association of ants with mealybug wilt disease of pineapple. Proc. Hawaiian Entomology Society, 36, 9-28.

Johnston, A. (1957). Bacterial heart rot of the pineapple. Malayan Agriculture Journal, 40:2-8.

Joy, P.P. and Sindhu, G. (2012). Disease of Pineapple
(Ananas comosus): Pathogen, Symptoms, Infection, Spread and Management. Kerala, India: Pineapple Research Station (Kerala Agricultural University).

Kaneshiro, W.S., Burger, M., Vine, B.G., De Silva, A.S. and Alvarez, A.M. (2008). Characterization of Erwinia chrysanthemi from a bacterial heart rot of pineapple outbreak in Hawaii. Plant Disease, 92(10), 1444-1450. https://doi.org/10.1094/PDIS-92-101444

Kim T.Y., Jang J.Y., Yu N.H., Chi W.J., Bae C.H., Yeo J.H., Park, A.R., Hur, J.-S., Park, H.W., Park, J.Y., Park, J.H., Lee, S.K. and Kim, J.C. (2018). Nematicidal activity of grammicin produced by Xylaria grammica KCTC 13121BP against Meloidogyne incognita. Pest Management Science, 74, 384-391. https://doi.org/10.1002/ps.4717

Kiriga, A.W., Haukeland, S., Kariuki, G.M., Coyne, D.L. and Beek, N.V. (2018). Effect of Trichoderma spp. and Purpureocillium lilacinum on Meloidogyne javanica in commercial pineapple production in Kenya. Biological Control, 119, 27-32. https:// doi.org/10.1016/j.biocontrol.2018.01.005

Kokalis-Burelle N., Rosskopf E.N., Butler D.M., Fennimore S.A. and Holzinger J. (2016). Evaluation of steam and soil solarization for Meloidogyne arenaria control in Florida floriculture crops. Journal of Nematology, 48(3), 183-192. https:// doi.org/10.21307/jofnem-2017-026

Korres, A.M.N., Buss, D.S., Ventura, J.A. and Fernandes, P.M.B. (2011). Candida krusei and Kloeckera apis inhibit the causal agent of pineapple Fusariosis, Fusarium guttiforme. Fungal Biology, 115(12), 1251-1258. https://doi.org/10.1016/ j.funbio.2011.09.001

Kuruppu, M., Siddiqui, Y., Ahmad, K. and Ali, A. (2020). First report of postharvest stem end rot disease on MD2 pineapple fruits caused by Neoscytalidium dimidiatum in Malaysia. Plant Disease, 105, 1564. https://doi.org/10.1094/PDIS-10 -20-2318-PDN

Larsen, L.D. (1910). Disease of Pineapple. Hawaiian Sugar Planters Association Pathol. Physiol. Ser. Experimental Station Bulletin, 10, 1-72.

Lim, T.K. and Rohrbach, K.G. (1980). Role of Penicillium funiculosum strains in the development of pineapple fruit diseases. Phytopathology, 70 (7),663-665. https://doi.org/10.1094/Phyto-70-663

Lim, W. (1985). Pathogenicity of Penicillium funiculosum strains from pineapple fruit blemishes. MARDI Research Bulletin, 13(2),166-171.

Luo, Z.W., He, F., Fan, H.Y., Wang, X.H., Hua, M., Hu, F.C., Li, X.H., Liu, Z.X. and Yu, N.T. (2012). First 
report of leaf spot disease caused by Exserohilum rostratum on pineapple in Hainan Province, China. Plant Disease, 96(3), 458-459. https:// doi.org/10.1094/PDIS-11-11-0979

Malaysian Pineapple Industry Board (MPIB). (2015). Malaysia targets world pineapple market. Malaysian Pineapple Industry Board-MPIB. Retrieved from website: www.pressreader.com/malaysia/themalaysian-reserve/ 20151201.

Malaysian Pineapple Industry Board (MPIB). (2017). MPIB Undertakes Five Initiatives to Boost Pineapple Production. Retrieved from website: http:// malaysiandigest.com/news/712932-mpib-undertakes -five-initiatives-to-boost-pineapple-production.html.

Masdek, H.N., Ismail, A.B., Zulkifli, M. and Malip, M. (2007). Paratylenchus sp. associated with pineapple yield decline. Journal of Tropical Agriculture and Food Science, 35(1),191-199.

Massé, D., Cassam, N., Hostachy, B., Iskra-Caruana, M.L., Darnaudery, M., Lefeuvre, P. and Lett, J.M. (2021). First report of three pineapple mealybug wilt -associated viruses in Queen Victoria pineapples in Reunion Island. Plant Disease, 105(3), 715. https:// doi.org/10.1094/PDIS-05-20-1068-PDN

Medina-Canales M.G., Terroba-Escalante P., Manzanilla -López R.H. and Tovar-Soto A. (2019). Assessment of three strategies for the management of Meloidogyne arenaria on carrot in Mexico using Pochonia chlamydosporia var. mexicana under greenhouse conditions. Biocontrol Science and Technology, 29(7), 671-685. https:// doi.org/10.1080/09583157.2019.1582267

Nogueira, S.R., Lima, F.S.O., Rocha, E.M. and Araújo, D.H.M. (2014). Fungicides in Fusariosis pineapple control in the state of Tocantins, Brazil. Revista de Ciências Agrárias, 37(4),447-455.

Noor Baiti, A.A., Nurul Shamimi, A.G., Rozlaily, Z. and Mohd Zaki, R. (2017). Evaluation of the Performance of MD2 Pineapple Clone on Peat Soil. Transactions of the Malaysian Society of Plant Physiology, 24, 134-138.

Nor, A.A.M., Zainol, R., Abdullah, R., Jaffar, N.S., Rasid, M.Z.A., Laboh, R., Shafawi, N.A. and Aziz, N.B.A. (2019). Dissemination pattern of bacterial heart rot (BHR) disease and screening of the disease resistance among commercial pineapple varieties in Malaysia. Malaysian Journal of Microbiology, 15 (4), 346-350.

Nurnadirah, M.N., Neni, K.C.M.R. and Yuziah, M.Y.N. (2018). Evaluation of Antifungal Activity of Antagonistic Bacteria Against Butt Rot Disease Pathogen of Pineapple. Walailak Journal
Agricultural Technology and Biological Sciences, 15 (4), 283-293. https://doi.org/10.48048/ wjst.2018.4040

Nyarko, J. and Asare-Bediako, E. (2019). First report of pineapple mealybug wilt-associated virus- 1 and-3 in Ghanaian pineapple. New Disease Reports, 40(18), 2044-0588 https://doi.org/10.5197/j.20440588.2019.040.018

Paull, R.E. and Reyes, M.E.Q. (1996). Preharvest weather conditions and pineapple fruit translucency. Scientia Horticulturae, 66(1-2), 59-67. https:// doi.org/10.1016/0304-4238(96)00905-3

Petty, G.J., Tustin, H.A. and Dicks, H.M. (2005). Control of black spot disease/fruitlet core rot in Queen pineapple with integrated mealybug, pineapple fruit mite and fungus control programmes. Acta Horticulturae, 702, 143-149. https:// doi.org/10.17660/ActaHortic.2006.702.17

Rabie, E.C. (2017). Nematode pests of pineapple. In Fourie, H., Spaull, V.W., Jones, R., Daneel, M.S., De Waele, D. (Eds.). Nematology in South Africa: A View from the 21st Century, p. 395-407. Switzerland: Springer International Publishing. https://doi.org/10.1007/978-3-319-44210-5_18

Ramachandran, K., Manaf, U.A. and Zakaria, L. (2015). Molecular characterization and pathogenicity of Erwinia spp. associated with pineapple [Ananas comosus (L.) Merr.] and papaya (Carica papaya L.). Journal of Plant Protection Research, 55(4), 396404. https://doi.org/10.1515/jppr-2015-0053

Reyes, M.E.Q. (1999). Use of microbial antagonists to control postharvest black rot of pineapple fruit. Hawaii, USA: University of Hawaii, $\mathrm{PhD}$ Dissertation.

Reyes, M.E.Q., Rohrbach, K.G. and Paull, R.E. (2004). Microbial antagonists control postharvest black rot of pineapple fruit. Postharvest Biology and Technology, 33, 193-203. https://doi.org/10.1016/ j.postharvbio.2004.02.003

Rohrbach, K.G. and Johnson, M.W. (2003). Pests, diseases and weeds. In Bartholomew, D.P., Paull, R.E. and Rohrbach K.G. (Eds.), The pineapple: botany, production and uses, p. 203-253. Oxon, UK: CAB International. https:// doi.org/10.1079/9780851995038.0203

Roldi, M., Dias-Arieira, C.R., Da Silva, S.A., Dorigo, O.F. and Machado, A.C.Z. (2017). Control of Meloidogyne paranaensis in coffee plants mediated by silicon. Nematology, 19, 245-250. https:// doi.org/10.1163/15685411-00003044

Sahilah, A.M., Rozeita, L., Umi Kalsum, M.S. and Son, R. (2008). Typing of Erwinia chrysanthemi isolated 
from Josapine pineapple in Malaysia using antimicrobial susceptibility, plasmid profiles, ERICPCR and RFLP analysis. International Food Research Journal, 15(3), 273-280.

Samson, R., Legendre, J.B., Christen, R., Fischer-Le Saux, M., Achouak, W. and Gardan, L. (2005). Transfer of Pectobacterium chrysanthemi (Burkholder et al., 1953) Brenner et al., 1973 and Brenneria paradisiaca to the genus Dickeya gen. nov. as Dickeya chrysanthemi comb. nov. and Dickeya paradisiaca comb. nov. and delineation of four novel species, Dickeya dadantii sp. nov., Dickeya dianthicola sp. nov., Dickeya dieffenbachiae sp. nov. and Dickeya zeae sp. nov. International Journal of Systematic and Evolutionary Microbiology, 55(4), 1415-1427. https://doi.org/10.1099/ijs.0.02791-0

Samson, R.A., Yilmaz, N., Houbraken, J., Spierenburg, H., Seifert, K.A., Peterson, S.W., Varga, J. and Frisvad, J.C. (2011). Phylogeny and nomenclature of the genus Talaromyces and taxa accommodated in Penicillium subgenus Biverticillium. Studies in Mycology, 70, 159-183. https://doi.org/10.3114/ sim.2011.70.04

Sánchez, V., Rebolledo, O., Picaso, R.M., Cárdenas, E., Córdova, J., González, O. and Samuels, G.J. (2007). In vitro antagonism of Thielaviopsis paradoxa by Trichoderma longibrachiatum. Mycopathologia, 163, 49-58. https://doi.org/10.1007/s11046-0060085-y

Sether, D.M. and Hu, J.S. (2002b). Closterovirus infection and mealybug exposure are necessary for the development of mealybug wilt of pineapple disease. Phytopathology, 92(9), 928-935. https:// doi.org/10.1094/PHYTO.2002.92.9.928

Sether, D.M. and Hu, J.S. (2001). The impact of pineapple mealybug wilt-associated virus-1 and reduced irrigation on pineapple yield. Australasian Plant Pathology, 30(1), 31-36. https:// doi.org/10.1071/AP00060

Sether, D.M. and Hu, J.S. (2002a). Yield impact and spread of Pineapple mealybug wilt associated virus-2 and mealybug wilt of pineapple in Hawaii. Plant Disease, 86(8), 867-874. https://doi.org/10.1094/ PDIS.2002.86.8.867

Sidik, S. and Sapak, Z. (2021). Evaluation of selected chemical pesticides for controlling bacterial heart rot disease in pineapples variety MD2. IOP Conference Series: Earth and Environmental Science, 757(1), 012072. $1315 / 757 / 1 / 012072$

Singh, H.K.B., Santhirasegaram, V., Razali, Z. and Somasundram, C. (2018). Effects of black rot on the antioxidant properties of Morris and Sarawak pineapple (Ananas comosus). In Mandal, D., Shukla, A.C. and Siddiqui, M.W. (Eds.). Sustainable Horticulture: Food, Health, and Nutrition, Vol. 2, p. 176-184. Waretown, USA: Apple Academic Press Inc. https://doi.org/10.1201/b22430-14

Sipes, B.S., Caswell-Chen, E.P., Sarah, J.-L. and Apt, W.J. (2005). Nematode parasites of pineapple. In: Luc, M., Sikora, R.A. and Bridge J. (eds). Plant parasitic nematodes in subtropical and tropical agricultural. $2^{\text {nd }}$ ed., p 709-731. Wallingford, UK: CABI Publishing. https:// doi.org/10.1079/9780851997278.0709

Sipes, B. and Wang, K.H. (2017). Pests, diseases and weeds. In Lobo, M.G. and Paull, RE. (Eds.), Handbook of pineapple technology: production, postharvest science, and nutrition, p. 62-88. West Sussex, UK: John Wiley and Sons, Ltd. https:// doi.org/10.1002/9781118967355.ch4

Snowdon, A.L. (2010). A Colour Atlas of Post-harvest Diseases and Disorders of Fruits and Vegetables Volume 1: General Introduction and Fruits. 2nd ed. London, United Kingdom: Manson Publishing Ltd.

Soler, A., Marie-Alphonsine, P.A., Quénéhervé, P., Prin, Y., Sanguin, H., Tisseyre, P., Daumur, R., Pochat, C., Dorey, E., Rodriguez, R.G. and Portal, N. (2021). Field management of Rotylenchulus reniformis on pineapple combining crop rotation, chemicalmediated induced resistance and endophytic bacterial inoculation. Crop Protection, 141, 105446. https:// doi.org/10.1016/j.cropro.2020.105446

Steingass, C.B., Glock, M., Schweiggert, R. and Carle, R. (2015). Studies into the phenolic patterns of different tissues of pineapple (Ananas comosus [L.] Merr.) infructescence by HPLC-DAD-ESI-MSN and GC-MS analysis. Analytical and Bioanalytical Chemistry, 407, 6643-6479. https://doi.org/10.1007/ s00216-015-8811-2

Stępień, Ł., Koczyk, G. and Waśkiewicz, A. (2013). Diversity of Fusarium species and mycotoxins contaminating pineapple. Journal of Applied Genetics, 54(3), 367-380. https://doi.org/10.1007/ s13353-013-0146-0

Swaroop Kumar, H.M. (2007). Pathological and biochemical investigations on stem-end rot disease in pineapple (Ananas comosus (L.) Merr.). India: University of Mysore, PhD Dissertation.

Thalip, A.A., Tong, P.S. and Ng, C. (2015). The MD2 'super sweet' pineapple (Ananas comosus): A new pineapple variety, $\mathrm{md} 2$, has been selected to spearhead Malaysia's new ambitions in pineapple export. UTAR Agriculture Science Journal, 1(4), 1517. 
Thompson, A. (1937). Pineapple fruit rots in Malaya. Malayan Agricultural Journal, 25(10), 407-420.

Trocoli, R., Monteiro, F., Santos, P. and De Souza, J. (2017). Field applications of Trichoderma reduce pineapple Fusariosis severity and increase fruit weight. Journal of Plant Pathology, 99(1), 225-228.

Ventura, J.A., Zambolim, L. and Chaves, G.M. (1993). Integrated management system for pineapple Fusarium disease control. Acta Horticulturae, 334, 439-454. https://doi.org/10.17660/ ActaHortic. 1993.334.48

Ventura, J.A., Costa, H., Cabral, J.R.S. and de Matos, A.P. (2009). 'Vitória': new pineapple cultivar resistant to Fusariosis. Acta Horticulturae, 822, 5155.

Vera Obando, N.Y., Maicelo Quintana, J.L., Guevara Heredia, E. and Oliva Cruz, S.M. (2017). Plant parasitic nematodes associated with pineapple cultivation (Ananas comosus) in Amazonas, Peru. Scientia Agropecuaria, 8(1), 79-84. https:// doi.org/10.17268/sci.agropecu.2017.01.08

Veronico, P., Paciolla, C., Sasanelli, N., De Leonardis, S. and Melillo, M.T. (2017). Ozonated water reduces susceptibility in tomato plants to Meloidogyne incognita by the modulation of the antioxidant system. Molecular Plant Pathology, 18(4), 529-539. https://doi.org/10.1111/mpp.12413

Viana, E.D.S., Sasaki, F.F.C., Reis, R.C., Junghans, D.T., Guedes, I.S.A. and Souza, E.G. (2020). Quality of fusariosis-resistant pineapple FRF 632, harvested at different maturity stages. Revista Caatinga, 33(2), 541-549. 21252020v33n226rc

Vignassa, M., Meile, J.C., Chiroleu, F., Soria, C., Leneveu-Jenvrin, C., Schorr-Galindo, S. and Chillet, M. (2021). Pineapple mycobiome related to fruitlet core rot occurrence and the influence of fungal species dispersion patterns. Journal of Fungi, 7(3), 175. https://doi.org/10.3390/jof7030175

Vilaplana, R., Pérez-Revelo, K. and Valencia-Chamorro, S. (2018). Essential oils as an alternative postharvest treatment to control fusariosis, caused by Fusarium verticillioides, in fresh pineapples (Ananas comosus). Scientia Horticulturae, 238, 255-263. https://doi.org/10.1016/j.scienta.2018.04.052

Wijeratnam, R.S.W., Hewajulige, I.G.N. and Abeyratne, N. (2005). Postharvest hot water treatment for the control of Thielaviopsis black rot of pineapple. Postharvest Biology and Technology, 36(3), 323327. https://doi.org/10.1016/ j.postharvbio.2005.01.003

Wijeratnam, R.S.W., Hewajulige, I.G.N. and Perera,
M.G.D.S. (2006). The control of black rot disease and the application of a novel wax formulation for extending storage life of pineapple. Acta Horticulturae, 702, 185-189. https:// doi.org/10.17660/ActaHortic.2006.702.24

Wijesinghe, C.J., Wijeratnam, R.S.W., Samarasekara, J.K.R.R. and Wijesundera, R.L.C. (2010). Biological control of Thielaviopsis paradoxa on Pineapple by an isolate of Trichoderma asperellum. Biological Control, 53(3), 285-290.

Wijesinghe, C.J., Wijeratnam, R.S.W., Samarasekara, J.K.R.R. and Wijesundera, R.L.C. (2011). Development of a formulation of Trichoderma asperellum to control black rot disease on pineapple caused by (Thielaviopsis paradoxa). Crop Protection, 30(3), 300-306. https://doi.org/10.1016/ j.cropro.2010.11.020

Xiang, N., Lawrence, K.S. and Donald, P.A. (2018). Biological control potential of plant growthpromoting rhizobacteria suppression of Meloidogyne incognita on cotton and Heterodera glycines on soybean: A review. Journal of Phytopathology, 166 (7-8), 449-458. https://doi.org/10.1111/jph.12712

Yilmaz, N., Visagie, C.M., Houbraken, J., Frisvad, J.C. and Samson, R.A. (2014). Polyphasic taxonomy of the genus Talaromyces. Studies in Mycology, 78, 175 -341. https://doi.org/10.1016/j.simyco.2014.08.001

Yogendra Singh, P.S. and Purohit, J. (2017). Biochemical, physiological and morphological characterization of the bacterial isolate causing stalk rot of sorghum as Erwinia chrysanthemi. International Journal of Current Microbiology and Applied Sciences, 6(4), 341-346. https:// doi.org/10.20546/ijcmas.2017.604.037

Zhong, L., Ai, Y., Chun, R. and Yi, Y. (2016). Identification of Curvularia clavata causing leaf spot on pineapple (Ananas comosus) in China. Canadian Journal of Plant Pathology, 38(2),250-253. https:// doi.org/10.1080/07060661.2016.1158743 